\title{
Interaksi Antara Pemanfaatan Media Pembelajaran dan Gaya Belajar Terhadap Hasil Belajar IPS Terpadu
}

\author{
Arsyad Abd. Gani ${ }^{1}$
}

${ }^{1}$ Pendidikan Pancasila dan Kewarganegaraan Universitas Muhammadiyah Mataram, arsyad.gani@gmail.com

\begin{tabular}{l} 
INFO ARTIKEL \\
Riwayat Artikel: \\
Diterima: $\quad$ 15-Agustus- \\
2018 \\
Disetujui: $18-S e p t e m b e r-$ \\
2018 \\
\hline
\end{tabular}

Kata Kunci:

pemanfaatan

media

gaya

belajar

\section{A. LATAR BELAKANG}

Sebagaimana diketahui bahwa manusia memiliki otak dengan karakteristik unik antara otak belahan kiri dan otak belahan kanan. Otak kanan memiliki karakteristik Long term memory, sedangkan otak belahan kiri tergolong dalam Sort term memori. Gagasan terkait[1]: (a) fungsi otak-pikiran sebagai sistem terbuka; (b) modalitas, kecerdasan, gaya belajar, dan kreativitas dalam belajar, serta cara-cara pengembangannya; (c) pemanfaatan musik, suara, relaksasi, gambar, humor, dan mimpi untuk membangun suasana bermain dan belajar secara efektif serta mengasyikkan dengan anak- anak, tanpa mengurangi hakikat pembelajaran; serta (d) aktivitas, kiat, dan saran yang mudah dilakukan untuk mengembangkan kemampuan belajar dan mengakses informasi melalui seluruh modalitas belajar yang kita miliki.

Salah satu karakteristik belajar yang berkaitan dengan menyerap, mengolah, dan menyampaikan informasi tersebut adalah gaya belajar peserta didik. Gaya belajar merupakan modalitas belajar yang sangat penting. Sebagian peserta didik bisa belajar dengan sangat baik hanya dengan cara melihat orang lain melakukannya. Para siswa menyukai cara penyajian informasi yang runtut. Selama pembelajaran, peserta didik suka 
menulis apa yang dikatakan pendidik. Peserta didik Visual ini berbeda dengan peserta didik Auditorial yang mengandalkan kemampuan untuk mendengar. Sedangkan peserta didik Kinestetik lebih suka belajar dengan cara terlibat langsung. Pembelajaran dapat melibatkan dua pihak yaitu siswa sebagai pembelajar dan guru sebagai fasiliasator[2]. Pembelajaran yang baik adalah pembelajaran dengan memberikan materi yang langsung dialami siswa atau dilihat siswa, pembelajaran disampaikan dengan menanamkan konsep dan karakteristik nilai esensial mata pelajaran[3].

Hal tersebut sesuai pernyataan bahwa gaya belajar terhadap Mahasiswa Kelas A didominasi oleh gaya belajar Visual (53\%), Kelas B didominasi gaya belajar Auditorial (35\%), dan Kelas C didominasi gaya belajar didominasi Visual (29\%). Secara keseluruhan, kecenderungan gaya belajar Mahasiswa didominasi oleh tipe gaya belajar Visual sebesar 33\%. Contoh karakteristik pembelajaran yang cocok untuk mahasiswa visual adalah memotivasi mahasiswa untuk menggambarkan informasi, dengan membuat diagram, simbol dan gambar berwarna dalam catatan mahasiswa Visual[1]. Demikian juga pendapat lain bahwa setiap siswa, baik yang mempunyai gaya belajar auditorial, visual, ataupun kinestetik mempunyai tingkat kemandirian belajar dan kemampuan pemecahan masalah matematik yang sama. Selain itu, diketahui pula bahwa semakin tinggi tingkat kemandirian belajar siswa, maka semakin tinggi pula kemampuan pemecahan masalah matematis siswa[4]. Penelitian selanjutnya menunjukkan ada peningkatan yang signifikan setelah penggunaan model pembelajaran tertentu dengan media tertentu untuk meningkatkan hasil belajar IPS, di mana rata-rata hasil belajar IPS siswa kelas V yang dibelajarkan menggunakan kooperatif tipe make a match berbantuan media grafis lebih besar dari siswa yang dibelajarkan menggunakan pembelajaran konvensional $\quad(78,08>73,63)$. Hasil analisis membuktikan bahwa terdapat perbedaan yang signifikan hasil belajar IPS antara siswa yang dibelajarkan menggunakan model pembelajaran kooperatif tipe make a match berbantuan media grafis dengan siswa yang dibelajarkan menggunakan pembelajaran konvensional (thitung $=3,423>$ ttabel=2,000). Dengan demikian dapat disimpulkan bahwa model pembelajaran kooperatif tipe make a match berbantuan media grafis berpengaruh secara signifikan terhadap hasil belajar IPS siswa kelas V SDN 18 Pemecutan[5].

Tantangan dunia pendidikan saat ini yaitu menerapkan sistem pendidikan yang memungkinkan optimalisasi seluruh otak sehingga penerimaan, pengolahan, penyimpanan dan penggunaan informasi terjadi secara efisien. Optimalisasi otak pada dasarnya adalah menggunakan seluruh bagian otak secara bersama-sama dengan melibatkan sebanyak mungkin alat indera secara serentak. Penggunaan berbagai media pembelajaran merupakan salah satu usaha membelajarkan seluruh bagian otak, baik otak kiri maupun kanan, rasional maupun emosional, atau bahkan spiritual. Permainan warna, bentuk, tekstur dan suara sangat dianjurkan. Dalam proses pembelajaran harus mampu menciptakan suasana gembira karena suasana gembira mempengaruhi cara kerja dalam memproses, menyimpan, mengolah dan memanfaatkan informasi.

Kondisi hereditas siswa yang memiliki karakteristik beragam dalam belajar juga menjadi salah satu aspek yang harus diperhatikan sungguh-sungguh oleh para pendidik. Varian latar belakang siswa baik faktor internal maupun eksternal sesungguhnya menjadi salah satu aspek yang mutlak dijadikan pertimbangan. Secara internal, kemampuan siswa memahami pelajaran baik yang mengandalkan indera penglihatan, indera pendengaran maupun dengan gerakan fisik turut berperan dalam menentukan siswa memahami pelajaran. Kehadiran media pembelajaran yang tepat dapat menjadi pemicu selain bagi perhatian siswa, daya tangkap dan juga kuatnya pengalaman belajar tersimpan dalam memori siswa. Oleh karena demikian peran lembaga pendidikan baik sekolah-sekolah maupun Perguruan Tinggi sangat menentukan bagaimana masa depan bangsa ini[6].

Guru di Kota Mataram dalam kenyataannya seringkali menemukan kesulitan dalam memilih dan menggunakan media pembelajaran, metode dan strategi yang bagaimana yang paling tepat untuk membahas satu materi pembelajaran, atau metode apakah yang paling diminati oleh sebagian besar siswa, sehingga tercipta pembelajaran yang aktif, inovatif, kreatif, edukatif, menyenangkan, gembira dan berbobot. Pada aspek pelaksanaan pembelajaran di Kota Mataram terdapat tiga faktor yaitu: (1) penguasaan konsep dalam pembelajaran saintifik yang interaktif, (2) pemanfaatan media dalam menciptakan karya, dan (3) penguasaan keterampilan apersepsi[7].

Sebuah penelitian tentang penggunaan media pada 100 orang guru IPS yang dilaksanakan di Kota Mataram menyimpulkan lima hal utama, yaitu: (1) $55 \%$ guru menggunakan media dalam pembelajaran IPS. (2) $23 \%$ guru pernah membuat media pembelajaran sendiri (teachers made media). (3) 97\% guru menggunakan alat peraga yang sudah tersedia di sekolah (ready made media). (4) $12 \%$ guru menggunakan media video dan televisi (audio-visual media), dan (5) 9\% guru menggunakan media computer dan LCD projector[8]. Penelitian lebih lanjut, tentang penggunaan media flashcard untuk meningkatkan hasil belajar IPS pada pembelajaran tematik di Sekolah Dasar, hasil penelitian menunjukkan bahwa aktivitas guru mengalami peningkatan sebesar $13,3 \%$ dari $76,3 \%$ pada siklus I menjadi $89,6 \%$ pada siklus II. Sedangkan aktivitas siswa mengalami peningkatan sebesar $12,5 \%$ dari $76,8 \%$ pada 
siklus I menjadi $89,3 \%$ pada siklus II.sedangkan ketuntasan klasikal hasil belajar siswa sebesar 24,3\% yaitu dari $69,6 \%$ pada siklus I menjadi $93,9 \%$ pada siklus II[9].

Sehubungan dengan simpulan penelitian tersebut, hasil observasi awal peneliti pada beberapa SMP yang ada di Kota Mataram bahwa mata pelajaran Ilmu Pengetahuan Sosial (IPS), guru sering kali menghadapi berbagai kendala dalam menyampaikan materi pembelajaran, khususnya dalam memilih media yang digunakan. Apalagi mata pelajaran IPS di SMP merupakan mata pelajaran non eksakta yang disampaikan secara terpadu terdiri dari materi Sejarah, Geografi dan Ekonomi. IPS oleh sebagian besar guru dianggap cukup kompleks dan membutuhkan pemahaman yang komprehensif pada semua sub mata pelajaran. Luas dan bervariasinya materi ini membutuhkan kerja keras dengan menggunakan media yang menarik agar pembelajaran tidak membosankan. Salah satunya dengan memanfaatkan media elektronik (video/multimedia). Multimedia pembelajaran IPS yang dikembangkan layak digunakan dalam kegiatan pembelajaran dan menjadi alternatif sumber belajar IPS khususnya siswa kelas V dengan materi peristiwa sekitar proklamasi[10].

Kesulitan guru dalam menyampaikan materi pelajaran secara terpadu tentu akan terus berlangsung apabila para guru khususnya guru IPS hanya menggunakan media konvensional. Sejatinya, Guru hendaknya melakukan inovasi dalam kegiatan pembelajarannya sehingga mampu meningkatkan minat dan kegemaran siswa dalam memahami ilmu-ilmu sosial.

Menurut beberapa siswa kelas IX SMP Negeri 15 Mataram, para siswa kesulitan dengan luasnya materi ajar yang harus dikuasai. Setiap pelajaran IPS, siswa mesti menyiapkan empat LKS (LKS geografi, sejarah, ekonomi dan sosiologi). Demikian pula dengan tugas yang diberikan guru. Setidaknya dalam satu semester, siswa dihadapkan dengan empat tugas yang berbeda sesuai dengan topik yang dibahas. Masalah lainnya yaitu pembelajaran yang membosankan karena biasanya dialokasikan pada jam terakhir. Ketika guru bercerita, banyak siswa mengantuk. Media pelajaran juga terbatas pada peta, globe dan gambar yang siswa ditugaskan untuk mencari sendiri. Selain itu, gaya belajar, minat dan bakat siswa dalam pembelajaran IPS juga berpotensi memberikan masalah tersendiri dalam mendukung hasil pembelajaran yang berkualitas dan bermakna.

\section{B. METODE PENELITIAN}

Penelitian menggunakan metode kuantitatif[11]. Tempat penelitian di SMP Negeri 13 Mataram. Waktu penelitian antara Oktober 2016 sampai dengan Desember 2016. Populasi terjangkau Siswa kelas VIII SMP Negeri 13 Mataram terdiri dari 224 orang siswa dengan gaya belajar visual. Uji instrumen penelitian diambil 30 orang. Sampel penelitian ini sebanyak 108 orang yang dibagi menjadi 54 orang kelompok eksperimen (dibelajarkan dengan multimedia) dan 54 orang kelompok kontrol (dibelajarkan dengan media konvensional). Pengambilan sampel dilakukan dengan teknik Random Sampling[12].

Data dikumpulkan dengan menggunakan instrumen tes hasil belajar dan angket gaya belajar. Data dianalisis dengan menggunakan teknik statistik deskriptif dan statistik inferensial. Statistik inferensial, digunakan pada analisis yang berkaitan dengan uji persyaratan analisis yaitu: (1) normalitas data; dan (2) homogenitas. Dan (3) Statistik multivariat, yakni teknik analisis yang akan digunakan untuk menjawab hipotesis yang diajukan[13]. Pengujian hipotesis penelitian dilakukan melalui Uji $\mathrm{F}$ yang dilanjutkan dengan uji post-hoc atau Uji Tukey.

\section{HASIL DAN PEMBAHASAN}

Penelitian ini adalah penelitian eksperimen dengan desain $2 \times 2$. Analisis dalam penelitian ini menggunakan perhitungan two ways ANOVA dengan sel yang sama. Berikut ringkasan hasil perhitungan Anava.

Tabel 1

Rangkuman Analisis Variansi Dua Jalan dengan Sel Sama

\begin{tabular}{|c|c|c|c|c|c|c|}
\hline Sumber & JK & dK & RK & F $_{\text {hitung }}$ & $\begin{array}{c}F_{\text {tabe }} \\
1\end{array}$ & $\begin{array}{l}\text { Kepu } \\
\text { tusan }\end{array}$ \\
\hline $\begin{array}{l}\text { Media } \\
\text { Pembelaj } \\
\text { aran (A) }\end{array}$ & $\begin{array}{l}172 \\
, 79\end{array}$ & 1 & $\begin{array}{l}172 \\
79\end{array}$ & 9,06 & 3,94 & $\begin{array}{l}\text { Ho } \\
\text { ditola } \\
\mathrm{k}\end{array}$ \\
\hline $\begin{array}{l}\text { Gaya } \\
\text { belajar } \\
\text { (B) }\end{array}$ & $\begin{array}{l}253 \\
, 72\end{array}$ & 1 & $\begin{array}{l}253 \\
72\end{array}$ & 13,31 & 3,94 & $\begin{array}{l}\text { Ho } \\
\text { ditola } \\
\mathrm{k}\end{array}$ \\
\hline $\begin{array}{l}\text { Interaksi } \\
\text { (AB) }\end{array}$ & $\begin{array}{l}83 \\
25\end{array}$ & 1 & $\begin{array}{l}83,2 \\
5\end{array}$ & 4,37 & 3,94 & $\begin{array}{l}\text { Ho } \\
\text { ditola } \\
\mathrm{k}\end{array}$ \\
\hline Galat & $\begin{array}{l}198 \\
2,5 \\
2\end{array}$ & 104 & $\begin{array}{l}19,0 \\
6\end{array}$ & - & - & - \\
\hline Total & $\begin{array}{l}24 \\
92 \\
29\end{array}$ & 107 & - & - & - & - \\
\hline
\end{tabular}

Mengacu pada tabel di atas dan kriteria pengujian rata-rata serta interaksi, dapat disimpulkan sebagai berikut:

\section{Pada Media pembelajaran (A) Ho ditolak}

Terdapat perbedaan efek media pembelajaran pada kelompok siswa dengan media pembejaran muliti media dengan kelompok siswa dengan media pembelajaran konvensional terhadap hasil belajarsiswa. Dengan kata lain, siswa yang diajarkan dengan media pembejaran muliti media memiliki hasil belajar yang berbeda dari siswa yang diajarkan dengan media pembelajaran konvensional.

\section{Pada gaya belajar (B) Ho ditolak}

Terdapat perbedaan efek gaya belajar baik pada siswa dengan gaya belajara uditorial dan siswa dengan gaya belajar visual terhadap hasil belajar siswa. Dengan kata lain siswa dengan gaya belajar auditorial memiliki hasil belajar yang berbeda dari siswa dengan gaya belajar visual 


\section{Pada interaksi (AB) Ho diterima}

Terdapat interaksi antara media pembelajaran dengan gaya belajar terhadap hasil belajar siswa. Artinya karakteristik perbedaan gaya belajar siswa pada setiap media pembelajaran tidak sama. Dengan kata lain, perbedaan hasil belajar dari masing-masing media pembelajaran tidak konsisten pada masing-masing gaya belajar dan adanya perbedaan prestasi belajar dari masing-masing Gaya belajar tidak konsisten pada masing-masing media pembelajaran.

\section{Terdapat pengaruh interaksi antara pemanfaatan media pembelajaran dan gaya belajar}

Hal ini disimpulkan berdasarkan hasil analisis data pada uji ANAVA yang menunjukkan bahwa menunjukkan $\mathrm{F}_{\text {Hitung }}(4,37)>\mathrm{F}_{\text {tabel }}(3,94)$ nilai dengan taraf signifikansi 0,05 .

\section{TEMUAN DAN DISKUSI}

Hasil penelitian ini mendukung teori yang menyatakan bahwa pembelajaran pada dasarnya merupakan suatu proses interaksi komunikasi antara sumber belajar, guru, dan siswa. Interaksi komunikasi itu dilakukan baik secara langsung dalam kegiatan tatap muka maupun secara tidak langsung dengan menggunakan media, dimana sebelumnya telah menentukan model pembelajaran yang akan diterapkan tentunya. Siswa tidak dianggap sebagai objek yang tidak tahu apa-apa. Siswa justru sebagai subjek yang memiliki latar belakang, minat, gaya belajar, karakteristik, kebutuhan serta kemampuan yang berbeda. Guru hendaknya mampu memahami perbedaan individu siswa sehingga tujuan instruksional dapat tercapai dengan efektif[14]. Oleh karena itu, guru, media pembelajaran, serta perbedaan individu dalam hal ini gaya belajar sebagai komponen yang saling mempengaruhi terhadap hasil belajar yang diperoleh siswa. Siswa dengan gaya belajar visual cenderung memiliki kemampuan fokus yang lebih baik. Demikian pula siswa dengan gaya belajar auditory cenderung bisa belajar dalam suasana bising dan mengandalkan kemampuan mendengarnya untuk memperoleh pengalaman belajar[14].

Sebagaimana hasil penelitian lainnya bahwa seorang yang bertipe visual, akan cepat mempelajari bahanbahan yang disajikan secara tertulis, bagan, grafik, gambar. Pokoknya mudah mempelajari bahan pelajaran yang dapat dilihat dengan alat penglihatannya. Sebaliknya merasa sulit belajar apabila dihadapkan bahan-bahan bentuk suara, atau gerakan yang menjadi kegemaran para pembelajar bergaya auditory[15].

Hasil penelitian lain menunjukkan bahwa from the perspective of students, being able to recognise their predominant style of learning provides an understanding of strengths and weaknesses in relation to learning opportunities in fieldwork. During a fieldwork placement a collaborative approach to learning is essential especially assisted by media utilization[16]. (dari perspektif siswa, kemampuan mengenal gaya belajar yang paling dominan dapat membantunya belajar lebih baik sehingga dia paham kelebihan dan kelemahannya dalam bekerja secara kolaboratif khususnya dalam pembelajaran dengan bantuan media).

Pemanfaatan media pembelajaran yang sifatnya kompleks baik dari aspek visual, audio maupun penggabungan antara media tersebut dalam satu jenis alat yang disebut multimedia. Hal ini memberikan indikasi bahwa gaya belajar siswa dapat pula ditingkatkan bilamana terjadi hubungan timbal balik antara penggunaan media yang tepat dan lengkap. Jadi dapat disimpulkanbahwa terdapat pengaruh interaksi antara pemanfaatan media pembelajaran dengan gaya belajar siswa.

Berdasarkan hasil penelitian dan teori yang mendukung, maka dapat simpulkan bahwa, dalam menerapkan beberapa media pembelajaran hendaknya seorang guru memperhatikan jenis gaya belajar siswa. Jika memungkinkan dalam pembagian kelas di sekolah jangan hanya berdasarkan prestasi atau perengkingan semata, tetapi pembagian kelas dapat juga didasarkan pada jenis gaya belajar siswa. Hal tersebut disarankan agar guru dapat memilih beberapa media pembelajaran yang dapat meningkatkan hasil belajar yang disesuaikan dengan jenis gaya belajar siswa dalam kelas, karena dengan pemanfaatan media pembelajaran yang tepat sesuai dengan kebutuhan siswa maka dapat dipastikan tercipta suasana belajar yang kondusif, dengan demikian hasil yang akan diperoleh siswa akan memuaskan semua pihak.

\section{E. SIMPULAN DAN SARAN}

Penerapan media belajar multimedia memberikan dampak yang berbeda bagi siswa dengan gaya belajar visual dan siswa dengan gaya belajar auditori. Hal ini tentu saja memberikan implikasi pada perolehan hasil belajar siswa. Temuan ini memberikan gambaran yang jelas pada dampak antara faktor-faktor utama yang turut mendukung perolehan hasil belajar IPS Terpadu siswa. Penerapan media belajar multimedia yang seharusnya menjadi pilihan bagi para guru di era digital ini hendaklah juga mempertimbangkan varian gaya belajar siswa. Sebab siswa dengan gaya belajar visual memiliki cara yang berbeda dengan siswa dengan gaya belajar auditori.

Hasil penelitian ini diharapkan akan berdampak pada meluasnya wawasan teoretis guru dan pengelola pendidikan sehingga memperkaya generalisasi tentang berbagai pengaruh variabel sesuai dengan teori-teori yang diverifikasi dalam analisis varian. Implikasi dari hasil penelitian adalah Peneliti menemukan bahwa terdapat perbedaan hasil belajar IPS Terpadu siswa 
dengan gaya belajar visual dengan siswa bergaya belajar auditori. Implikasinya adalah gaya belajar turut memberikan dampak sebagai penyebab berbedanya kemampuan siswa memahami pembelajaran, melalui: (1) penting bagi guru untuk mengetahui varian gaya belajar siswa yang sedang dididiknya. (2) Semakin rinci bagi guru memahami karakteristik siswanya, maka guru semakin mudah memberikan treatmen yang sesuai dengan karakteristik tersebut. (3) Kebiasaan sekolah melakukan tes inteligensi disetiap awal tahun pelajaran hendaknya juga memberikan data memadai terkait gaya belajar siswa.

\section{UCAPAN TERIMA KASIH}

Penulis mengucapkan terima kasih kepada pihak Universitas Muhammadiyah Mataram yang senantiasa memberikan saran, masukan, dan dana pada penulis sehingga artikel ilmiah ini selesai dengan tepat waktu.

\section{DAFTAR RUJUKAN}

[1] A. K. Sari, "Analisis Karakteristik Gaya Belajar VAK (Visual, Auditorial, Kinestetik) Mahasiswa Pendidikan Informatika Angkatan 2014," EduticScientific J. Informatics Educ., vol. 1, no. 1, 2014.

[2] R. Susilana, M. Si, and C. Riyana, Media pembelajaran: hakikat, pengembangan, pemanfaatan, dan penilaian. CV. Wacana Prima, 2008.

[3] B. Herijanto, "Pengembangan CD Interaktif Pembelajaran IPS Materi Bencana Alam," J. Educ. Soc. Stud., vol. 1, no. 1, 2012.

[4] R. Ramlah, D. Firmansyah, and H. Zubair, "Pengaruh Gaya Belajar dan Keaktifan Siswa Terhadap Prestasi Belajar Matematika (Survey Pada SMP Negeri di Kecamatan Klari Kabupaten Karawang)," Maj. Ilm. SOLUSI, vol. 1, no. 03, 2015 .

[5] K. M. Dewi, I. M. Putra, and I. B. S. Manuaba, "Pengaruh Model Pembelajaran Kooperatif Tipe Make a Match berbantuan Media Grafis terhadap Hasil Belajar IPS Siswa Kelas V SDN 18 Pemecutan," Mimb. PGSD Undiksha, vol. 1, no. 1, 2013.

[6] S. Saddam, D. L. Setyowati, and J. Juhadi, "Integrasi Nilai-nilai Konservasi dalam Habituasi Kampus untuk Pembentukan Kepribadian Mahasiswa Universitas Negeri Semarang," $J$. Educ. Soc. Stud., vol. 5, no. 2, pp. 128-135, 2016.

[7] M. A. Rasidi and F. A. Setiawati, "Faktor-Faktor Kesulitan Guru Pada Pembelajaran Tematik Integratif Di Sd Kota Mataram," J. Prima Edukasia, vol. 3, no. 2, pp. 155-165, 2015.

[8] S. Sanisah, "Pendidikan tinggi dan pengangguran terbuka: Sebuah dilema," Lentera Pendidik. J. Ilmu Tarb. dan Kegur., vol. 13, no. 2, pp. 147-159, 2010.

[9] L. Maghfiroh, "Penggunaan Media Flashcard untuk Meningkatkan Hasil Belajar IPS pada Pembelajaran Tematik di Sekolah Dasar," $J$. Penelit. Pendidik. Guru Sekol. Dasar, vol. 1, no. 2, pp. 1-13, 2013.

[10] A. M. Fanny and S. P. Suardiman,
"Pengembangan multimedia interaktif untuk mata pelajaran ilmu pengetahuan sosial (IPS) sekolah dasar kelas V," J. Prima Edukasia, vol. 1, no. 1, pp. 1-9, 2013.

[11] Sudaryono, Metode Penelitian Pendidikan. Jakarta: Prenadamedia Group, 2016.

[12] P. Sugiyono, Metode Penelitian Kuantitatif, Kualitatif, dan R\&D. 2013.

[13] Sugiyono, "Metode Penelitian kuantitatif kualitatif dan R dan D," Alf. Bandung, 2010.

[14] D. K. Rusman and C. Riyana, "Pembelajaran Berbasis Teknologi dan Komunikasi: Mengembangkan Profesionalitas Guru.” Jakarta: RajaGrafindo Persada, 2012.

[15] A. L. Bire, U. Geradus, and J. Bire, "Pengaruh gaya belajar visual, auditorial, dan kinestetik terhadap prestasi belajar siswa," J. Kependidikan Penelit. Inov. Pembelajaran, vol. 44, no. 2, 2014.

[16] L. Robertson, T. Smellie, P. Wilson, and L. Cox, "Learning styles and fieldwork education: Students' perspectives," New Zeal. J. Occup. Ther., vol. 58, no. 1, p. 36, 2011. 